\title{
Laser Irradiation of Mung Bean (Vigna radiata L.) at Two Wavelengths for Enhanced Seedling Development
}

\author{
Rayno Vic B. Janayon $\mathbb{I D}^{1,2}$ and Raphael A. Guerrero $\mathbb{i D}^{1}$ \\ ${ }^{1}$ Department of Physics, School of Science and Engineering, Ateneo de Manila University, Loyola Heights, \\ Quezon City, Philippines \\ ${ }^{2}$ Physics Department, College of Natural Sciences and Mathematics, Mindanao State University, Marawi City, Philippines
}

Correspondence should be addressed to Raphael A. Guerrero; rguerrero@ateneo.edu

Received 27 May 2019; Revised 2 August 2019; Accepted 26 August 2019; Published 16 September 2019

Academic Editor: Giulio Cerullo

Copyright (C) 2019 Rayno Vic B. Janayon and Raphael A. Guerrero. This is an open access article distributed under the Creative Commons Attribution License, which permits unrestricted use, distribution, and reproduction in any medium, provided the original work is properly cited.

\begin{abstract}
Two laser sources operating at wavelengths of $632.8 \mathrm{~nm}(\mathrm{He}-\mathrm{Ne})$ and $488 \mathrm{~nm}\left(\mathrm{Ar}^{+}\right)$are used in examining the effects of coherent, low-power, continuous wave exposure on the development of Vigna radiata L. Presowing laser irradiation of seeds leads to an improvement of mung bean seedling characteristics, with increased values of hypocotyl length (an increase of up to 22.5\%), root length (an increase of up to 28.8\%), and seedling mass (a maximum increase of 29.2\%). Measured parameters between seedlings from laser-irradiated seeds and from control samples are statistically different at a level of significance equal to 0.05 . For both laser wavelengths, an optimal exposure time of 2 minutes is determined for enhanced growth of mung bean seedlings.
\end{abstract}

\section{Introduction}

Since the first demonstration of laser action in 1960 by Theodore H. Maiman [1], lasers have been used in numerous scientific, military, and industrial applications. In agriculture, lasers have been applied as biostimulators since this biophysical method does not change the course of physiological processes controlled by genetic systems [2]. Lowintensity laser light has been employed to provide biostimulation for seeds such as soybean, maize, and peas, leading to an increase in germination percentage, weight, and yield $[3,4]$. As a physical method to improve sowing material, laser irradiation is considered safe for the environment [5]. Compared to other methods available for presowing treatment of seeds, laser-based methods are beneficial and cost-effective [6] and may even reduce the danger of soil and water contamination [7].

The stimulating effect of laser irradiation originates from the interaction between polarized light and plant photoreceptors [8]. Photoreceptors present in plants include phytochromes for sensing red/far-red light, the UV-B photoreceptor UVR8 (UV Resistance Locus 8), blue light- sensing cryptochromes, phototropins, and Zeitlupe family members [9]. These photoreceptors absorb light [10], with their specific absorption properties matching the spectrum of incident radiation [11].

Many studies have previously reported the effects of laser irradiation on seed vigor, seed germination, and seedling development. The absorbed energy from laser light activates physiological and biochemical processes within seeds due to the conversion of light energy into chemical energy [12]. Laser irradiation significantly influenced germination and development of faba bean seeds by increasing enzyme activity, resulting in the earlier maturity of plants [13]. Presowing treatment with a $\mathrm{He}-\mathrm{Ne}$ laser improved the rate of germination and morphological characteristics of peas [14], enhanced the final germination percentage of radish seeds [15], and increased the amylolytic enzyme activity, number of free radicals, and indole-3-acetic acid (IAA) content in seeds and seedlings of white lupine and faba bean [16]. He$\mathrm{Ne}$ irradiation has also protected soybean stands from fungi [17] and has led to better resistance to cold and earlier plant maturity of maize, spring wheat, spring barley, and sugar beet seedlings [18]. Mung bean (Vigna radiata L.) under $\mathrm{Ar}^{+}$ 
laser exposure manifested an increase in fresh and dry weights, as well as in RNA, DNA, and protein content [19].

Mung bean is among the most important pulse crops in South, East, and Southeast Asia, which accounts for $90 \%$ of the global production. This leguminous crop is a significant source of protein, carbohydrates, and a range of macronutrients [20]. Grown because of its high nitrogen content, mung bean serves as a source of protein found in a typical Southeast Asian diet [21].

In 2016, the Philippine production of mung bean yielded only 34,039 metric tons (MT) and an almost equivalent amount of $31,232 \mathrm{MT}$ had to be imported to meet the annual domestic requirement of about 65,000 MT [22]. One of the reasons behind low mung bean production is a shortage of quality seeds of improved and adaptable varieties [23]. As the primary motivation of this current paper, we believe that the agricultural productivity of mung bean may be increased through a presowing treatment based on laser irradiation. Low-dose laser treatment of plants is known to enhance the bioenergetic potential of cells and accompanying biochemical and physiological processes [24]. Our experimental design makes use of two readily available laser wavelengths for the irradiation process. Hypocotyl length, root length, and increase in mass are the parameters examined for mung bean seedlings. To the best of our knowledge and based on extensive reviews of scientific literature by Hernandez-Aguilar et al. in 2010 and $2016[12,25]$, where they proposed the use of lasers in agriculture with different purposes including the improvement of physiological quality, we are the first to report the effects of laser exposure (at $632.8 \mathrm{~nm}$ and $488 \mathrm{~nm}$ ) on these plant characteristics for Vigna radiata L.

\section{Materials and Methods}

Our experiments consist of two main components. A standard protocol was followed in preparing the mung bean samples for laser irradiation. Treatment with coherent radiation was then performed with conventional turnkey laser sources and standard optical elements. Seedling mass and hypocotyl and root lengths were measured, and the appropriate statistical analysis was applied. Details of each experimental aspect are provided below. A randomized complete block design was used in this study [26].

2.1. Seed Preparation and Germination. Mung bean seeds were sourced from a local supermarket in Quezon City, Philippines. Before preparing the samples for laser treatment, the reflectance spectra of representative mung bean seeds were obtained using an Ocean Optics USB2000 spectrometer and a Mikropack DH-2000 broadband light source. The seeds were then washed with distilled water and soaked in water for $24 \mathrm{~h}$ [27]. The seeds were soaked in water to promote germination and to facilitate the removal of seed coats. Prior to laser irradiation, the seed coats were removed using tweezers. The seed coat removal made the plant emergence faster and increased the root dry weight of citrus rootstocks [28]. In addition, the removal of seed coats significantly enhanced the germination percentage of Prunus yedoensis [29] and mango varieties [30]. After exposure to laser light, each batch of seeds was allowed to germinate in a Petri dish lined with clean tissue paper. Ten seeds were placed in each container. The Petri dishes were placed under darkroom conditions in a custom chamber measuring $63 \mathrm{~cm} \times 54 \mathrm{~cm} \times 42 \mathrm{~cm}$. Temperature inside the chamber was maintained at $24^{\circ} \mathrm{C}$ and relative humidity at $80 \%$. Our measured relative humidity during germination was within the range of $70 \%[31,32]$ and $90 \%$ [33], which is similar to that reported in other studies on the laser irradiation of seeds. During germination, the seeds were sprinkled daily with $2 \mathrm{ml}$ of water using a syringe.

2.2. Laser Treatment. Seed irradiation was performed with two laser sources. A $10 \mathrm{~mW} \mathrm{He}-\mathrm{Ne}$ laser (JDS Uniphase) was employed for exposure at $\lambda=632.8 \mathrm{~nm}$, and a $30 \mathrm{~mW}$ $\mathrm{Ar}^{+}$laser (Spectra-Physics) was used for illumination at $\lambda=488 \mathrm{~nm}$. Neutral density filters were applied to generate an output power of $10 \mathrm{~mW}$ for the $\mathrm{Ar}^{+}$laser. Salyaev et al. [34] and Gonzalez et al. [35] used a similar power rating to irradiate the mitochondria of maize seedlings and kudzu seeds, respectively. Figure 1 is a schematic diagram of the setup for subjecting mung bean seeds to laser light for both wavelengths. With each laser source, the beam was expanded with a lens $(f=2.5 \mathrm{~cm})$ and an aperture. The light was redirected to the seeds with a mirror. Mung bean seeds were placed on clean tissue paper in a fixed position directly below the mirror for irradiation. The laser light illuminated the embryonic side of the seed $[6,26]$. For each batch of exposed samples, 4 seeds were irradiated within the final beam diameter of $2 \mathrm{~cm}$. In our experiments, six irradiation time intervals were applied: $0 \mathrm{~s}$ (control, no exposure), $30 \mathrm{~s}$, $1 \mathrm{~min}, 2 \mathrm{~min}, 5 \mathrm{~min}$, and $10 \mathrm{~min}$. A digital stopwatch was used as a timer during exposition. The same exposure periods were applied in a related study according to Govil et al. [19].

2.3. Measurement of Seedling Characteristics. For each exposure time, we measured hypocotyl and root lengths for 100 mung bean seedlings after a germination period of 5 days. Chen and Han [36] followed a similar protocol for wheat seeds. Digital photographs of seedlings were recorded, and ImageJ v.1.51 h software [37] was used to determine plant dimensions.

The increase in seedling mass was determined after 12 , 24, 48, 72, 96, and $120 \mathrm{~h}$, as reported by Podleśny et al. [16] for both white lupine and faba bean. The masses were measured with a digital weighing scale (Pocket scale, $\mathrm{MH}$ 300) for three replicates of 30 randomly selected seedlings.

2.4. Statistical Analysis. Experimental results were subjected to an analysis of variance (ANOVA) [33], and a Tukey test [38] was applied to determine the significant differences among irradiation times. The tests were performed using the $\mathrm{R}$ software. Level of significance was tested at $p=0.05$. 


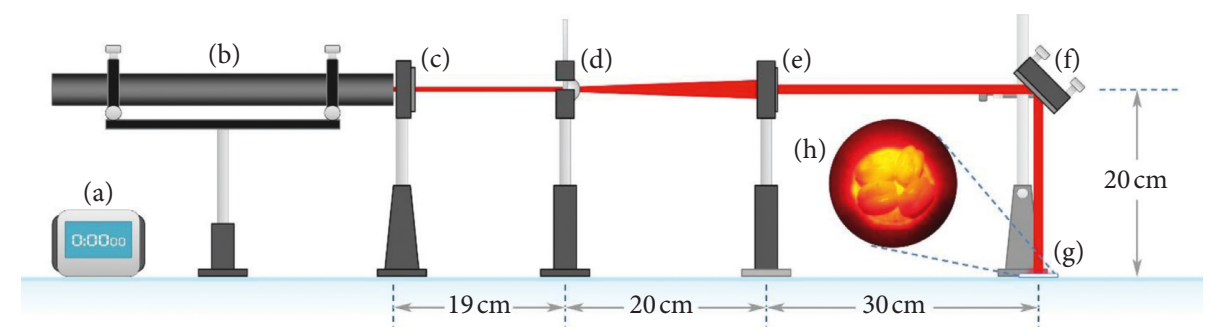

FIGURE 1: Optical system for laser irradiation of mung bean seeds: (a) digital stopwatch; (b) laser; (c) neutral density filter (used only for $\mathrm{Ar}^{+}$ laser); (d) lens; (e) aperture; (f) mirror; (g) mung bean seeds; (h) actual image of irradiated seeds.

\section{Results and Discussion}

The normalized spectra in Figure 2 indicate that the reflectance of mung bean seeds is higher at $632.8 \mathrm{~nm}$ than at $488 \mathrm{~nm}$. Reflectance behavior for seeds with or without seed coats is similar at the two relevant laser wavelengths. Mung bean seeds exhibit a generally uniform maximum reflectance from $539 \mathrm{~nm}$ to $642 \mathrm{~nm}$.

For both $\mathrm{He}-\mathrm{Ne}$ and $\mathrm{Ar}^{+}$sources, laser treatment of seeds had a pronounced effect on the early development of Vigna radiata L. Figure 3 plots the mean hypocotyl length and mean root length of 5-day-old mung bean seedlings for each exposure time at $\lambda=632.8 \mathrm{~nm}$ using the He-Ne laser. For untreated seeds, the average hypocotyl length is $95.4 \mathrm{~mm}$. Hypocotyls of irradiated seeds are generally longer than those of the untreated samples, with an increase of $14 \%$ after only $30 \mathrm{~s}$ of exposure. Longer hypocotyls are obtained as exposure time is extended to $1 \mathrm{~min}$, with an increase of $20.9 \%$, and $2 \mathrm{~min}(22.5 \%$ increase $)$. Mean length of the hypocotyl with a $2 \mathrm{~min}$ exposure increases to $116.9 \mathrm{~mm}$. Enhancement of the hypocotyl length is reduced when applying exposure times beyond $2 \mathrm{~min}$, with increases of only $19.8 \%$ and $5.9 \%$ for 5 and $10 \mathrm{~min}$ exposures, respectively.

Improvement in the root length of mung bean seedlings as a result of $\mathrm{He}-\mathrm{Ne}$ laser irradiation was also observed. Untreated root length on average is $81.9 \mathrm{~mm}$, with the value increasing to 90.8 (10.8\% increase) and $105.5 \mathrm{~mm}(28.8 \%$ increase) for 1 and 2 min exposure intervals, respectively. As with hypocotyl length, enhancement of root length drops with exposure times longer than $2 \mathrm{~min}$. The increase in length is $21.8 \%$ and $8.2 \%$, respectively, for 5 and $10 \mathrm{~min}$ treatments.

Figure 4 illustrates how hypocotyl length and root length are also influenced by the illumination of mung bean seeds at the $\mathrm{Ar}^{+}$laser wavelength of $488 \mathrm{~nm}$. All seedlings from irradiated seeds have longer mean hypocotyl lengths than plants from unexposed samples. We note, however, that the improvement in length is reduced compared to the results obtained with the He-Ne laser. With a control hypocotyl length of $95.4 \mathrm{~mm}$, exposure times of $30 \mathrm{~s}$ and $1 \mathrm{~min}$ result in increases of only $1.8 \%$ and $6.8 \%$, respectively. The largest increase $(15.9 \%)$ in this seedling parameter still occurs with an irradiation time of $2 \mathrm{~min}$, with the average hypocotyl length of $110.6 \mathrm{~mm}$. Average values decrease at 5 and $10 \mathrm{~min}$ exposure times, with increases of $11 \%$ and $5.3 \%$, respectively.

In the absence of laser exposure, the mean root length is $81.9 \mathrm{~mm}$, increasing slightly by $0.8 \%$ with $30 \mathrm{~s}$ of irradiation.

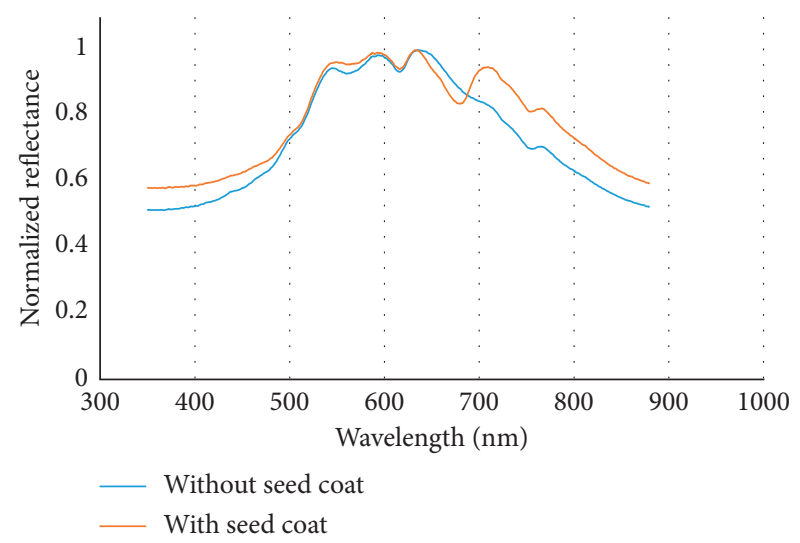

FiguRE 2: Normalized reflectance spectra for mung bean seeds.

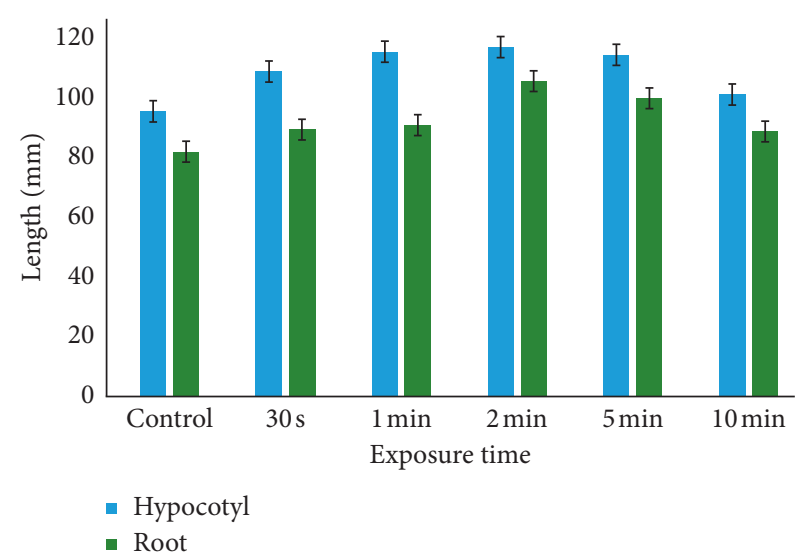

FIgURE 3: Effect of laser irradiation at $\lambda=632.8 \mathrm{~nm}$ on the hypocotyl length and root length of mung bean seedlings. Laser treatment leads to longer seedlings with an optimal exposure time of $2 \mathrm{~min}$. Error bars represent standard deviations.

Increases of $4.3 \%$ and $10.5 \%$ are noted for 1 and $2 \mathrm{~min}$ exposure intervals, respectively, with the maximum average root length measured at $90.6 \mathrm{~mm}$ for $2 \mathrm{~min} .5$ and $10 \mathrm{~min}$ exposures yield lower increases of $8.2 \%$ and $2 \%$, respectively. As with experimental results for hypocotyl length, the enhancement in root development is lower than that observed when irradiating seeds at $632.8 \mathrm{~nm}$.

Mean values of hypocotyl length and root length of mung bean seedlings resulting from different laser irradiation times are presented in Table 1. In terms of hypocotyl length, all exposure times for both $632.8 \mathrm{~nm}$ and 


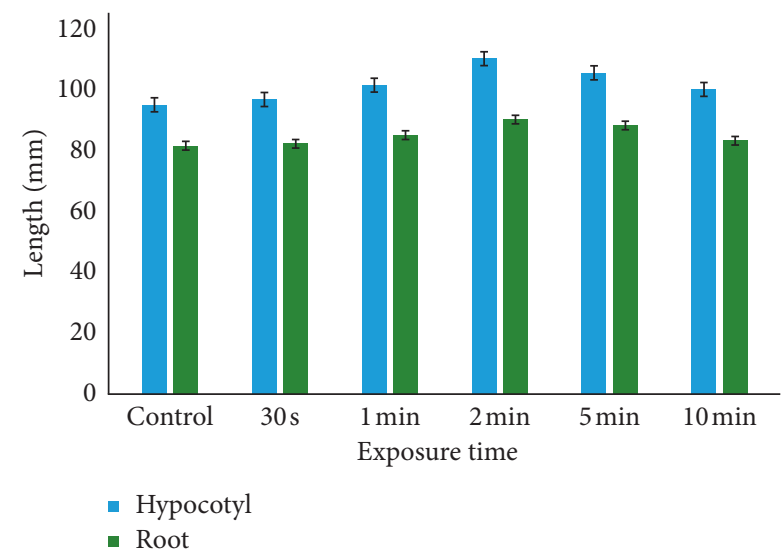

FIGURE 4: Effect of laser irradiation at $\lambda=488 \mathrm{~nm}$ on the hypocotyl length and root length of mung bean seedlings. Lengths are improved after laser treatment, with an optimal exposure time of 2 min. Error bars represent standard deviations.

$488 \mathrm{~nm}$ lead to statistically different values with respect to control seedlings from unexposed seeds. He-Ne laser irradiation caused a significant difference in the root length of mung bean seedlings, excluding the $10 \mathrm{~min}$ exposure interval. No significant difference was observed among the root lengths of mung bean seedlings as a result of seed irradiation with an $\mathrm{Ar}^{+}$laser. Govil et al. [19] reported a significant effect on the root length of mung bean seedlings arising from $\mathrm{Ar}^{+}$laser exposure at $\lambda=514.5 \mathrm{~nm}$ with an output power of $1 \mathrm{~W}$. Enhancement from laser biostimulation has been established to be dependent on the applied wavelength, irradiation time, and irradiation dose [12]. Better results with the $\mathrm{He}-\mathrm{Ne}$ laser are attributed to mung bean photoreceptor phytochromes having more sensitivity to red light [12]. Despite seeds having a lower reflectance at $488 \mathrm{~nm}$, the enhanced phytochrome response at $632.8 \mathrm{~nm}$ is the dominant factor in terms of promoting seedling development. Phytochromes are known to absorb blue light weakly, but the two photoreversible forms Pr and Pfr absorb more red light [39].

Our results for the improvement in hypocotyl length due to seed biostimulation with laser light are consistent with reports in the literature. Podleśny et al. [16] discussed the positive effects on the elongation of hypocotyls of white lupine and faba bean, while Drozd and Szajsner [40] observed an elongation of the hypocotyl of cucumber. In addition, Urva et al. [26] noticed an increase in the shoot length of Moringa oleifera effected by laser irradiation. On the positive influence of $\mathrm{He}-\mathrm{Ne}$ irradiation on the root development of mung bean, Metwally et al. [41] recorded a significant increase in root length of Celosia argentea, while Qiu et al. [27] reported longer roots of wheat seedlings. Podleśny et al. [16] also observed a significant difference in the root length of white lupine and faba bean between treated and untreated seeds. Chen and Han [36] found that low doses of He-Ne laser light promote plant height and root length of 5-day-old wheat seedlings. Due to a rise in seed internal energy as a result of laser irradiation, accelerated enzyme activity promotes cell division during seed germination [4].
TABLE 1: Mean values of hypocotyl length and root length of 5-dayold mung bean seedlings after laser pretreatment of seeds at $\lambda=632.8 \mathrm{~nm}$ and $\lambda=488 \mathrm{~nm}$.

\begin{tabular}{|c|c|c|c|c|}
\hline \multirow[b]{2}{*}{$\begin{array}{l}\text { Exposure } \\
\text { time }\end{array}$} & \multicolumn{2}{|c|}{$\begin{array}{l}\text { He-Ne laser } \\
(\lambda=632.8 \mathrm{~nm})\end{array}$} & \multicolumn{2}{|c|}{$\operatorname{Ar}^{+}$laser $(\lambda=488 \mathrm{~nm})$} \\
\hline & $\begin{array}{c}\text { Hypocotyl } \\
\text { length }(\mathrm{mm})\end{array}$ & $\begin{array}{l}\text { Root } \\
\text { length } \\
(\mathrm{mm})\end{array}$ & $\begin{array}{c}\text { Hypocotyl } \\
\text { length }(\mathrm{mm})\end{array}$ & $\begin{array}{c}\text { Root } \\
\text { length } \\
(\mathrm{mm})\end{array}$ \\
\hline $\begin{array}{l}0 \mathrm{~s} \\
\text { (control) }\end{array}$ & $95.443^{\mathrm{a}}$ & $81.936^{\mathrm{a}}$ & $95.443^{\mathrm{a}}$ & $81.936^{\mathrm{a}}$ \\
\hline $30 \mathrm{~s}$ & $108.766^{b c}$ & $89.319^{\mathrm{ab}}$ & $97.183^{\mathrm{ab}}$ & $82.562^{\mathrm{a}}$ \\
\hline $1 \mathrm{~min}$ & $115.403^{\mathrm{c}}$ & $90.829^{\mathrm{ab}}$ & $101.914^{\mathrm{ac}}$ & $85.444^{\mathrm{a}}$ \\
\hline $2 \mathrm{~min}$ & $116.925^{\mathrm{c}}$ & $105.529^{c}$ & $110.647^{\mathrm{C}}$ & $90.572^{\mathrm{a}}$ \\
\hline $5 \mathrm{~min}$ & $114.358^{\mathrm{c}}$ & $99.793^{b c}$ & $105.981^{\mathrm{bc}}$ & $88.623^{\mathrm{a}}$ \\
\hline $10 \mathrm{~min}$ & $101.075^{\mathrm{ab}}$ & $88.688^{\mathrm{a}}$ & $100.529^{\mathrm{ab}}$ & $83.583^{\mathrm{a}}$ \\
\hline
\end{tabular}

Means with different superscripts in the same column are statistically different at $p=0.05$.

In Figures 5 and 6, we show how seedling mass is enhanced via laser irradiation of seeds at $\lambda=632.8 \mathrm{~nm}$ and $\lambda=488 \mathrm{~nm}$, respectively. Behavior at different exposure times is plotted vs. hours of plant growth. With seed treatment at $\lambda=632.8 \mathrm{~nm}$ (Figure 5), all irradiated samples exhibited larger masses compared to the control seeds, within a 12 to $120 \mathrm{~h}$ period of development. Exposure of seeds for 2 min created an optimal increase in mass for plant growth after $24 \mathrm{~h}$. After $120 \mathrm{~h}$, seedlings from the 2 min irradiation batch had an average mass increase of $13.9 \mathrm{~g}$, a $29.2 \%$ improvement relative to the untreated plants. Lower improvements in mass are measured for longer exposure times: $18.3 \%$ and $4 \%$ for 5 and $10 \mathrm{~min}$, respectively.

For the data obtained after irradiation at $488 \mathrm{~nm}$ (Figure 6), similar behavior is seen, with irradiated seeds developing into heavier plants regardless of exposure time, within a growth period of 12 to $120 \mathrm{~h} .2 \mathrm{~min}$ is still the best exposure time at this wavelength. The mean mass increase of seedlings from the 2 min exposure treatment is $12.4 \mathrm{~g}$, which is larger than the average additional mass of untreated plants by $15.5 \% .5$ and 10 min irradiation intervals generate increases of only $8.4 \%$ and $5.9 \%$, respectively.

Table 2 provides a summary of average seedling mass increase for laser treatment of seeds at $\lambda=632.8 \mathrm{~nm}$. Each column contains data for a specific period of growth, from 12 to $120 \mathrm{~h}$. In every column, the difference in seedling mass is statistically significant for all exposure times, with respect to the unexposed seeds. The only exception is the $72 \mathrm{~h}$ period for seeds that underwent $30 \mathrm{~s}$ of laser irradiation. Values for mass increase in seedlings from seeds illuminated with laser light at $488 \mathrm{~nm}$ are also statistically different from that of control plants, as detailed in Table 3. A sole exception is the data for $30 \mathrm{~s}$ exposure after $48 \mathrm{~h}$ of growth.

The increase in mass of mung bean seedlings is attributed to faster water uptake and metabolic processes in treated seeds, as noted by Krawiec et al. [38] in their study involving improved radicle length and dry weight of scorzonera seedlings brought about by laser stimulation. Our results agree with the observations by Podleśny et al. [16] regarding the influence of laser irradiation on the mass of germinating 


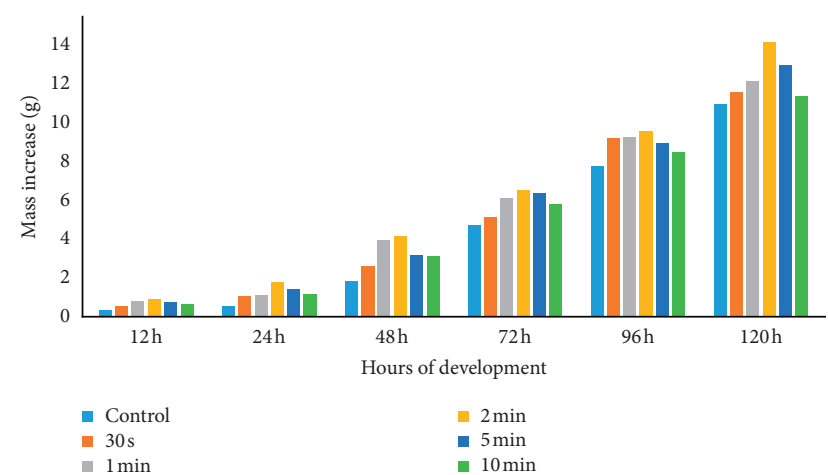

Figure 5: Enhancement of seedling mass due to laser irradiation at $\lambda=632.8 \mathrm{~nm}$ vs. hours of plant growth. Results for different exposure times are plotted at each time interval.

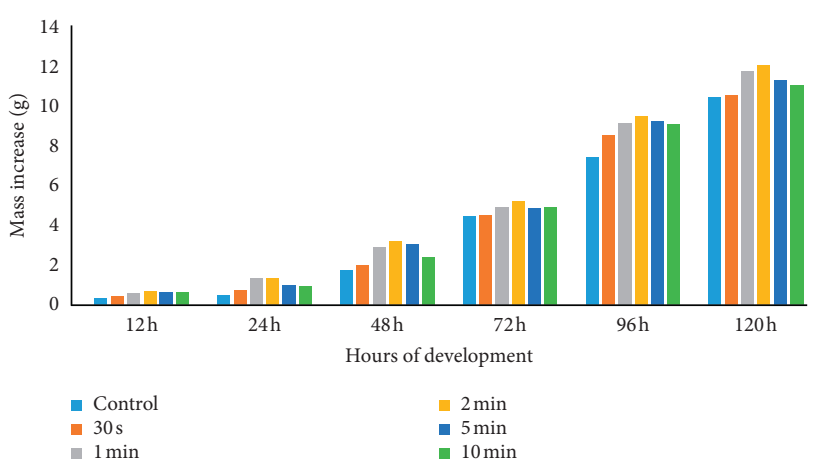

FIGURE 6: Enhancement of seedling mass due to laser irradiation at $\lambda=488 \mathrm{~nm}$ vs. hours of plant growth. Results for different exposure times are plotted at each time interval.

TABLE 2: Mean increase of seedling mass at each growth interval for different exposure times at $\lambda=632.8 \mathrm{~nm}$.

\begin{tabular}{lcccccc}
\hline $\begin{array}{l}\text { Time of } \\
\text { exposure }\end{array}$ & $12 \mathrm{~h}$ & $24 \mathrm{~h}$ & $48 \mathrm{~h}$ & $72 \mathrm{~h}$ & $96 \mathrm{~h}$ & $120 \mathrm{~h}$ \\
\hline Control & $0.333^{\mathrm{a}}$ & $0.500^{\mathrm{a}}$ & $1.800^{\mathrm{a}}$ & $4.600^{\mathrm{a}}$ & $7.633^{\mathrm{a}}$ & $10.733^{\mathrm{a}}$ \\
$30 \mathrm{~s}$ & $0.533^{\mathrm{ab}}$ & $1.033^{\mathrm{b}}$ & $2.533^{\mathrm{b}}$ & $5.000^{\mathrm{a}}$ & $9.033^{\mathrm{b}}$ & $11.366^{\mathrm{ab}}$ \\
$1 \mathrm{~min}$ & $0.800^{\mathrm{bc}}$ & $1.100^{\mathrm{b}}$ & $3.866^{\mathrm{d}}$ & $6.000^{\mathrm{bc}}$ & $9.066^{\mathrm{b}}$ & $11.900^{\mathrm{bc}}$ \\
$2 \mathrm{~min}$ & $0.866^{\mathrm{c}}$ & $1.733^{\mathrm{d}}$ & $4.066^{\mathrm{d}}$ & $6.366^{\mathrm{c}}$ & $9.366^{\mathrm{b}}$ & $13.866^{\mathrm{d}}$ \\
$5 \mathrm{~min}$ & $0.733^{\mathrm{bc}}$ & $1.400^{\mathrm{c}}$ & $3.133^{\mathrm{c}}$ & $6.266^{\mathrm{c}}$ & $8.766^{\mathrm{ab}}$ & $12.700^{\mathrm{c}}$ \\
$10 \mathrm{~min}$ & $0.633^{\mathrm{ac}}$ & $1.133^{\mathrm{b}}$ & $3.066^{\mathrm{c}}$ & $5.666^{\mathrm{b}}$ & $8.300^{\mathrm{ab}}$ & $11.166^{\mathrm{ab}}$ \\
\hline
\end{tabular}

Means with different superscripts in the same column are statistically different at $p=0.05$.

TABLE 3: Mean increase of seedling mass at each growth interval for different exposure times at $\lambda=488 \mathrm{~nm}$.

\begin{tabular}{lcccccc}
\hline $\begin{array}{l}\text { Time of } \\
\text { exposure }\end{array}$ & $12 \mathrm{~h}$ & $24 \mathrm{~h}$ & $48 \mathrm{~h}$ & $72 \mathrm{~h}$ & $96 \mathrm{~h}$ & $120 \mathrm{~h}$ \\
\hline Control & $0.333^{\mathrm{a}}$ & $0.500^{\mathrm{a}}$ & $1.800^{\mathrm{a}}$ & $4.600^{\mathrm{a}}$ & $7.633^{\mathrm{a}}$ & $10.733^{\mathrm{a}}$ \\
$30 \mathrm{~s}$ & $0.466^{\mathrm{ab}}$ & $0.766^{\mathrm{b}}$ & $2.033^{\mathrm{a}}$ & $4.633^{\mathrm{ab}}$ & $8.800^{\mathrm{b}}$ & $10.833^{\mathrm{ab}}$ \\
$1 \mathrm{~min}$ & $0.633^{\mathrm{b}}$ & $1.367^{\mathrm{c}}$ & $3.000^{\mathrm{c}}$ & $5.033^{\mathrm{c}}$ & $9.367^{\mathrm{b}}$ & $12.100^{\mathrm{cd}}$ \\
$2 \mathrm{~min}$ & $0.700^{\mathrm{b}}$ & $1.400^{\mathrm{c}}$ & $3.267^{\mathrm{c}}$ & $5.333^{\mathrm{c}}$ & $9.733^{\mathrm{b}}$ & $12.400^{\mathrm{d}}$ \\
$5 \mathrm{~min}$ & $0.667^{\mathrm{b}}$ & $1.000^{\mathrm{b}}$ & $3.167^{\mathrm{c}}$ & $5.000^{\mathrm{bc}}$ & $9.500^{\mathrm{b}}$ & $11.633^{\mathrm{bcd}}$ \\
$10 \mathrm{~min}$ & $0.667^{\mathrm{b}}$ & $0.967^{\mathrm{b}}$ & $2.467^{\mathrm{b}}$ & $5.033^{\mathrm{c}}$ & $9.333^{\mathrm{b}}$ & $11.367^{\mathrm{ac}}$ \\
\hline
\end{tabular}

Means with different superscripts in the same column are statistically different at $p=0.05$. seeds of faba bean and white lupine, with treated seeds growing in mass more quickly during imbibition compared to the control samples.

Laser pretreatment of seeds shows promise as a viable method for increasing mung bean productivity. The straightforward optical design involved in our method for enhancing plant development using laser radiation may be easily adapted for use in large-scale farming operations. An examination of laser irradiation of rice (Oryza sativa) seeds would be an interesting continuation of this work.

\section{Conclusion}

We have demonstrated how pretreatment of seeds via laser irradiation at $\lambda=632.8 \mathrm{~nm}$ and $\lambda=488 \mathrm{~nm}$ enhances the growth and development of Vigna radiata L. Experiments with our simple optical system have led to improvements in hypocotyl length and root length of mung bean seedlings by as much as $22.5 \%$ and $28.8 \%$, respectively, in comparison with untreated control samples. The mass of 5-day-old seedlings was also increased by a maximum of $29.2 \%$. Ideal results for all seedling parameters were obtained with an optimal irradiation time of $2 \mathrm{~min}$.

\section{Data Availability}

The data on enhanced seedling characteristics used to support the findings of this study are available from the corresponding author upon request.

\section{Disclosure}

R. A. Guerrero is a recipient of the Rev. Francis J. Heyden, S. J. Professorial Chair in Physics. R. V. B. Janayon is a scholar under the Commission on Higher Education Faculty Development Program-Phase II.

\section{Conflicts of Interest}

The authors declare that there are no conflicts of interest regarding the publication of this paper.

\section{Acknowledgments}

Assistance during the initial stages of experiments was provided by T. A. R. Conde. Statistical analysis was performed with the help of I. J. Aldema and A. P. Sumobay. The authors thank M. D. Dengal for her help with certain illustrations. Some equipment was purchased through a grant provided by the Philippine Council for Industry, Energy and Emerging Technology Research and Development (PCIEERD).

\section{References}

[1] T. H. Maiman, "Stimulated optical radiation in ruby," Nature, vol. 187, no. 4736, pp. 493-494, 1960.

[2] G. Vasilevski, "Perspectives of the application of biophysical methods in sustainable agriculture," Bulgarian Journal of Plant Physiology, vol. 179-186, 2003. 
[3] A. Aladjadjiyan, "The use of physical methods for plant growing stimulation in Bulgaria," The Journal of Central European Agriculture, vol. 8, no. 3, pp. 369-380, 2007.

[4] R. Perveen, Q. Ali, M. Ashraf, F. Al-Qurainy, Y. Jamil, and M. Raza Ahmad, "Effects of different doses of low power continuous wave $\mathrm{He}-\mathrm{Ne}$ laser radiation on some seed thermodynamic and germination parameters, and potential enzymes involved in seed germination of sunflower (Helianthus annuus L.)," Photochemistry and Photobiology, vol. 86, no. 5, pp. 1050-1055, 2010.

[5] J. Podleśny and A. Podleśna, "Morphological changes and yielding of chosen legumes plants under influence of seeds treatment by laser light," International Agrophysics, vol. 18, no. 3, pp. 253-260, 2004.

[6] Y. Jamil, R. Perveen, M. Ashraf, Q. Ali, M. Iqbal, and M. R. Ahmad, "He-Ne laser-induced changes in germination, thermodynamic parameters, internal energy, enzyme activities and physiological attributes of wheat during germination and early growth," Laser Physics Letters, vol. 10, no. 4, article 045606, 2013.

[7] A. Aladjadjiyan, "Alternative solutions for the treatment of food produce," in Case Studies in Food Safety and Environmental Health. Integrating Safety and Environmental Knowledge into Food Studies towards European Sustainable Development, Springer, Boston, MA, USA, 2007.

[8] M. P. Bielozierskich and T. A. Zolotariewa, "Laser treatment of seeds (in Russian)," Sacharnaja Swiowkla, vol. 2, pp. 32-33, 1981.

[9] M. Heijde and R. Ulm, "UV-B photoreceptor-mediated signalling in plants," Trends in Plant Science, vol. 17, no. 4, pp. 230-237, 2012.

[10] E. P. Spalding and K. M. Folta, "Illuminating topics in plant photobiology," Plant, Cell and Environment, vol. 28, no. 1, pp. 39-53, 2005.

[11] A. Möglich, X. Yang, R. A. Ayers, and K. Moffat, "Structure and function of plant photoreceptors," Annual Review of Plant Biology, vol. 61, no. 1, pp. 21-47, 2010.

[12] A. C. Hernandez, P. A. Dominguez, O. A. Cruz et al., "Laser in agriculture," International Agrophysics, vol. 24, no. 4, pp. 407-422, 2010.

[13] J. Podleśny, "Effect of laser irradiation on the biochemical changes in seeds and the accumulation of dry matter in the faba bean," International Agrophysics, vol. 16, no. 3, pp. 209-213, 2002.

[14] A. Podleśna, B. Gadyszewska, J. Podleśny, and W. Zgrajka, "Changes in the germination process and growth of pea in effect of laser seed irradiation," International Agrophysics, vol. 29, no. 4, pp. 485-492, 2015.

[15] S. Muszyński and B. Gladyszewska, "Representation of He-Ne laser irradiation effect on radish seeds with selected germination indices," International Agrophysics, vol. 22, no. 2, pp. 151-157, 2008.

[16] J. Podleśny, A. Stochmal, A. Podleśna, and L. E. Misiak, "Effect of laser light treatment on some biochemical and physiological processes in seeds and seedlings of white lupine and faba bean," Plant Growth Regulation, vol. 6, no. 3, pp. 227-233, 2012.

[17] S. A. Ouf and N. F. Abdel-Hady, "Influence of He-Ne laser irradiation of soybean seeds on seed mycoflora, growth, nodulation, and resistance to Fusarium solani," Folia Microbiologica, vol. 44, no. 4, pp. 388-396, 1999.

[18] R. Koper, "Pre-sowing laser biostimulation of seeds of cultivated plants and its results in agrotechnics," International Agrophysics, vol. 8, no. 4, pp. 593-596, 1994.
[19] S. R. Govil, D. C. Agrawal, K. P. Rai, and S. N. Thakur, "Physiological responses of Vigna radiata $\mathrm{L}$. to nitrogen and $\operatorname{argon}^{+}$laser irradiation," Indian Journal of Plant Physiology, vol. 34, no. 1, pp. 72-76, 1991.

[20] R. M. Nair, R.-Y. Yang, W. J. Easdown et al., "Biofortification of mungbean (Vigna radiata) as a whole food to enhance human health," Journal of the Science of Food and Agriculture, vol. 93, no. 8, pp. 1805-1813, 2013.

[21] E. F. Delfin, E. S. Paterno, F. G. Torres, and P. J. A. Santos, "Biomass, nitrogen uptake and fixed nitrogen partitioning in field grown mungbean (Vigna radiata $\mathrm{L}$. Wilczek) inoculated with Bradyrhizobium sp.," The Philippine Journal of Crop Sciences, vol. 33, no. 3, pp. 24-33, 2008.

[22] Supply Utilization Accounts of Selected Agricultural Commodities (Philippine Statistics Authority), 2017, https://psa. gov.ph/content/supply-and-utilization-accounts-selectedagricultural-commodities-1.

[23] FIESTA Tackles Mung Bean Production Concerns, 2018, http://www.pcaarrd.dost.gov.ph/home/portal/index.php/ quick-information_dispatch/3193-fiesta-tackles-mungbeanproduction-concerns.

[24] W. Rybiński, "Influence of laser beams on the variability of traits in spring barley," International Agrophysics, vol. 14, no. 2, pp. 227-232, 2000.

[25] C. H. Aguilar, A. D. Pacheco, A. C. Orea et al., "Laser biostimulation in seeds and plants," Gayana Botanica, vol. 73, no. 1, pp. 132-149, 2016.

[26] S. R. Urva, H. Shafique, Y. Jamil et al., "Low power continuous wave-laser seed irradiation effect on Moringa oleifera germination, seedling growth and biochemical attributes," Journal of Photochemistry and Photobiology B: Biology, vol. 170, pp. 314-323, 2017.

[27] Z. Qiu, J. Li, M. Zhang, Z. Bi, and Z. Li, "He-Ne laser pretreatment protects wheat seedlings against cadmium-induced oxidative stress," Ecotoxicology and Environmental Safety, vol. 88, pp. 135-141, 2013.

[28] E. A. Girardi, F. D. A. A. Mourão Filho, and R. A. Kluge, "Effect of seed coat removal and controlled-release fertilizer application on plant emergence and vegetative growth of two citrus rootstocks," Fruits, vol. 62, no. 1, pp. 13-19, 2007.

[29] D. H. Kim, "Practical methods for rapid seed germination from seed coat-imposed dormancy of Prunus yedoensis," Scientia Horticulturae, vol. 243, pp. 451-456, 2018.

[30] B. M. Muralidhara, Y. T. N. Reddy, V. Srilatha, and H. J. Akshitha, "Effect of seed coat removal treatments on seed germination and seedling attributes in mango varieties," International Journal of Fruit Science, vol. 16, no. 1, pp. 1-9, 2016.

[31] L. Yang, R. Han, and Y. Sun, "Damage repair effect of He-Ne laser on wheat exposed to enhanced ultraviolet-B radiation," Plant Physiology and Biochemistry, vol. 57, pp. 218-221, 2012.

[32] Z.-B. Qiu, X. Liu, X.-J. Tian, and M. Yue, "Effects of $\mathrm{CO}_{2}$ laser pretreatment on drought stress resistance in wheat," Journal of Photochemistry and Photobiology B: Biology, vol. 90, no. 1, pp. 17-25, 2008.

[33] A. Michtchenko and M. Hernandez, "Photobiostimulation of germination and early growth of wheat seeds (Triticum aestivum L) by a $980 \mathrm{~nm}$ semiconductor laser," Revista Cubana de Física, vol. 27, no. 2, pp. 271-274, 2010.

[34] R. K. Salyaev, L. V. Dudareva, T. A. Konenkina, A. S. Arziev, S. V. Lankevich, and E. G. Rudikovskaya, "Effect of low-intense laser radiation on the lipid composition of mitochondrial membranes of the maize (Zea mays L.) seedlings," Doklady Biological Sciences, vol. 419, no. 1, pp. 146-147, 2008. 
[35] S. Gonzalez, D. Fortes, and R. S. Herrera, "Effect of different doses of laser radiation on the germination of kudzu (Pueraria phaseoloides) seeds," Cuban Journal of Agricultural Science, vol. 42, no. 1, pp. 91-93, 2008.

[36] H. Chen and R. Han, "He-Ne laser treatment improves the photosynthetic efficiency of wheat exposed to enhanced UV-B radiation," Laser Physics, vol. 24, no. 10, article 105602, 2014.

[37] C. A. Schneider, W. S. Rasband, and K. W. Eliceiri, "NIH Image to ImageJ: 25 years of image analysis," Nature Methods, vol. 9, no. 7, pp. 671-675, 2012.

[38] M. Krawiec, A. Dziwulska-Hunek, S. Palonka, M. Kaplan, and P. Baryla, "Effect of laser irradiation on seed germination and root yield of scorzonera (Scorzonera hispanica L.)," Acta Agrophysica, vol. 23, no. 4, pp. 621-631, 2016.

[39] J. Li, G. Li, H. Wang, and X. W. Deng, "Phytochrome signaling mechanisms," The Arabidopsis Book, vol. 2011, no. 9, Article ID e0148, 2011.

[40] D. Drozd and H. Szajsner, "The reaction of seeds of some cucumber cultivars to pre-sowing laser biostimulation," Roczniki Akademii Rolniczej w Poznaniu, vol. 41, pp. 455-459, 2007, in Polish.

[41] S. A. Metwally, M. Abou-Ellail, B. H. Abo-Leila, and K. A. Aboud, "Effect of laser radiation on the growth, anatomical and biochemical genetic markers of Celosia argentea plants," International Journal of Academic Research, vol. 5, no. 3, pp. 200-206, 2013. 

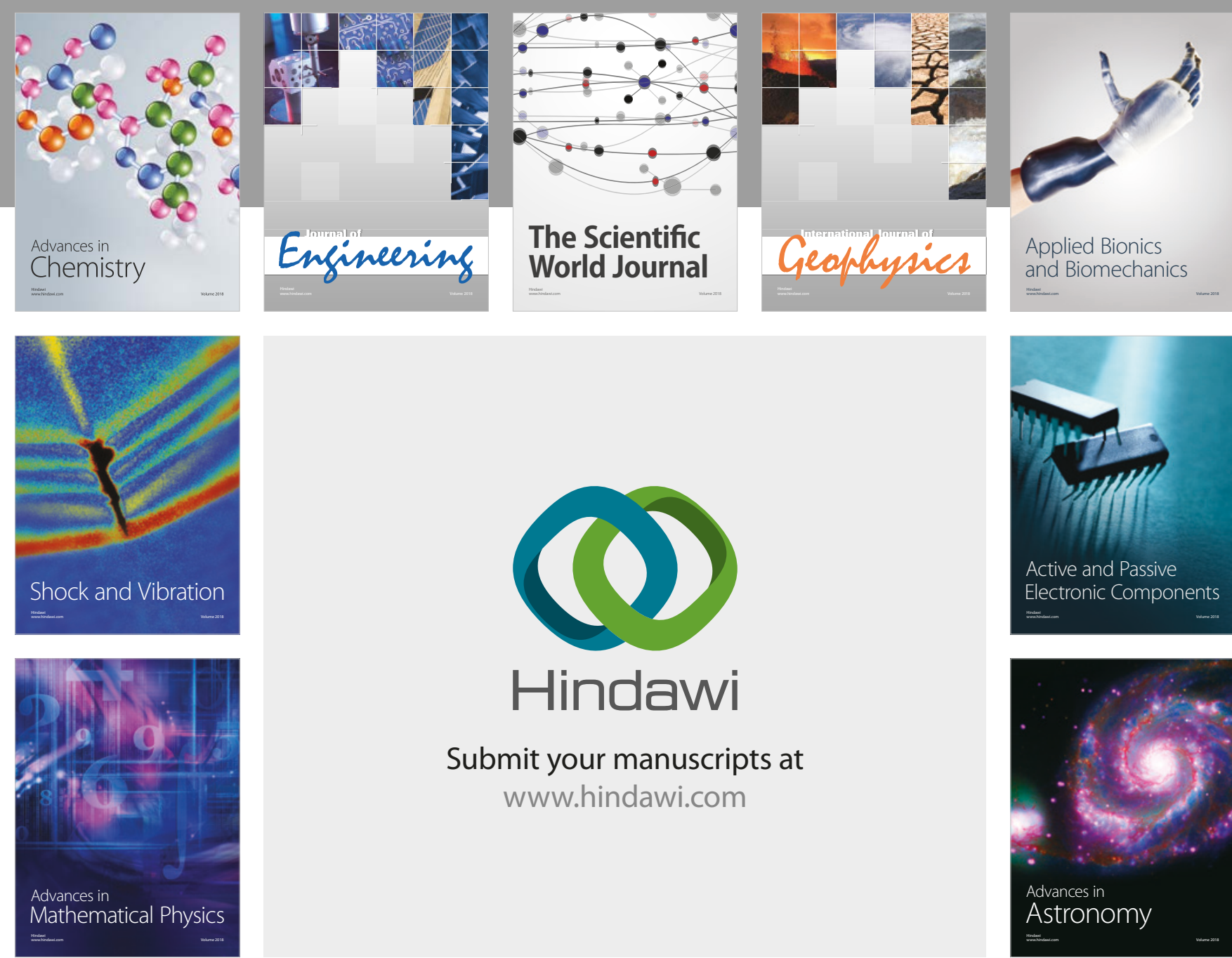

Submit your manuscripts at

www.hindawi.com

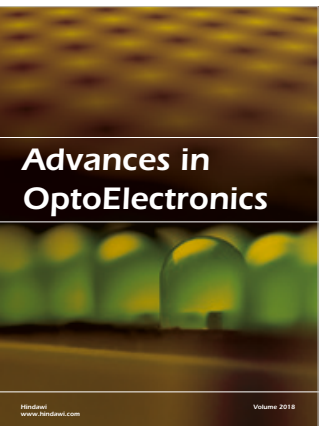

\section{Rotcting Machinery}
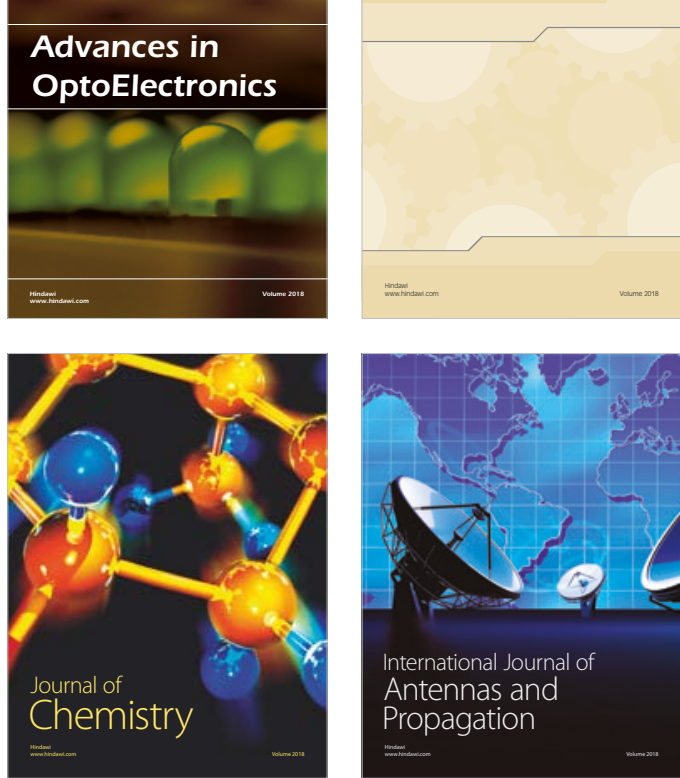

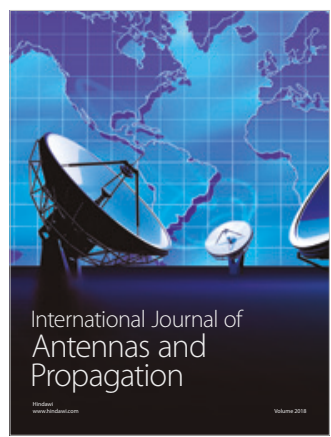

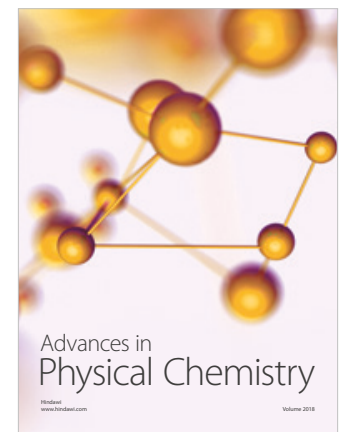

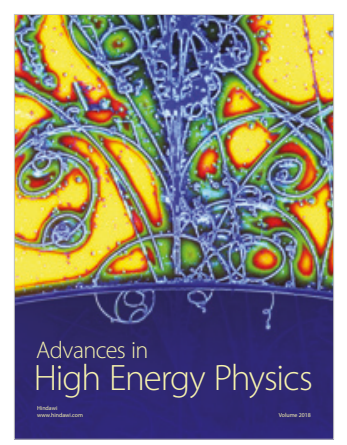

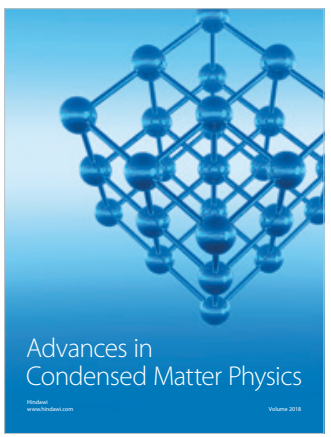

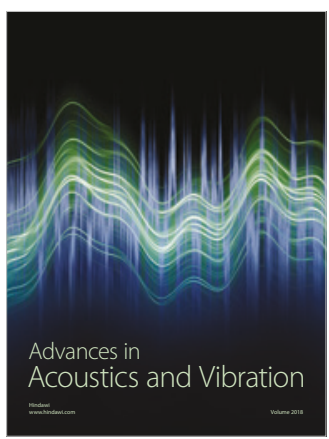

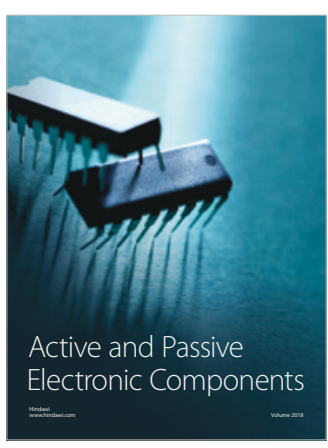
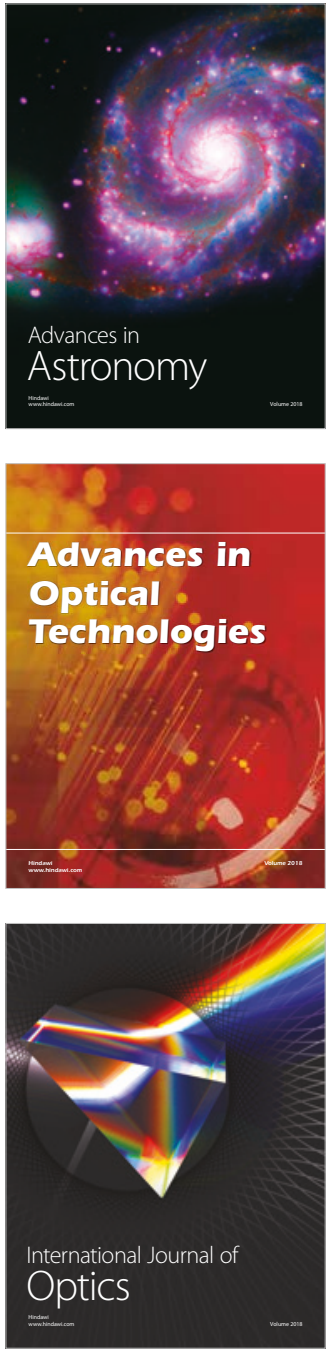